\title{
The medical-legal framework of work-related accidents in the field of social security medicine for protection from common disease in Italy: a comparative analysis of some emblematic cases
}

\author{
Michele Sammicheli, Marcella Scaglione \\ Forensic Medical Doctor, Medical Legal Department of Italian Institute of Social Security (INPS), Siena, Italy
}

\begin{abstract}
The Authors examine the critical issues that can arise in relation to the medical-legal evaluation of impairments caused by work-related accidents if included together with common diseases, i.e. not due to work or war, in the assessment to qualify for ordinary incapacity benefits from INPS (the Italian Social Security Institute). After a brief introduction to the Italian laws and regulations in this sector, the Authors present some emblematic cases to highlight operational procedures and consequent practical difficulties that a correct attribution of origin to injury - whether work-related or otherwise - can entail.
\end{abstract}

\section{RIASSUNTO}

Gli Autori esaminano le criticità che la valutazione medico legale delle menomazioni conseguenti ad infortunio sul lavoro possono presentare qualora incluse, assieme alla malattia comune, cioè non riconducibile a causa di lavoro o di guerra, tra quelle valutate ai fini del riconoscimento dell'assegno ordinario di invalidità erogato, in Italia, dall'INPS (Istituto Nazionale della Previdenza Sociale). Dopo una breve introduzione della normativa legislativa italiana nel settore, gli Autori, attraverso la descrizione di alcuni casi emblematici, espongono le modalità operative e le conseguenti difficoltà pratiche che una corretta attribuzione della genesi lavorativa e non della menomazione possono presentare.

\section{RESUMEN}

Los autores examinan las críticas que puede presentar la evaluación médico-legal de los impedimentos resultantes de un accidente de trabajo, en Italia, si se incluye, junto con la enfermedades que no dependen del trabajo o de la guerra, entre los evaluados para el reconocimiento del subsidio de invalidez ordinario otorgado por el INPS (Instituto Nacional de Seguridad Social de Italia). Después de una breve introducción de la legislación italiana en el sector, los autores, a través de la descripción de algunos casos emblemáticos, establecieron las modalidades operativas y las consiguientes dificultades prácticas que puede presentar una atribución correcta de la génesis de trabajo y no de la discapacidad.

\section{Introduction}

Work-related accidents, understood as injuries to workers by violent causes occurring in the workplace or during work, are covered in Italy by the National Institute for Insurance against Accidents at Work (INAIL). Article 2 of the Consolidated Text of Presidential Decree no. 1124 of $1965^{1}$ stipulates that "the insurance covers all cases of accidents that occur due to violent causes during work and result in death or a permanent incapacity to work, whether absolute or partial, or a temporary absolute incapacity requiring abstention from work for more than three days". Medical-legal elements specific to work-related accidents include the existence of a risk, a violent cause, the occurrence at work and the consequent bodily impairments, firstly to the general capacity to work and, more recently, to psycho-physical integrity (biological damage). 2,3 The INAIL Unified Text of 1965 covered temporary or permanent disability, whether partial or absolute, understood as the beneficiary's capacity to work. Legislative Decree no. 38 of $2000,{ }^{4}$ with regard to protection from occupational disease, introduced a concept that became central to civil liability: biological damage. This term refers to the damage to a person's psycho- physical integrity that is susceptible to medical-legal evaluation; therefore, biological damage does not only include the work capacity, but also mental capacity, the ability to procreate, aesthetic damage, etc. The economic relief of disability caused by work can be in the form of capital, in the case of biological damage between $6 \%$ and $15 \%$, based on the tables annexed to the Ministerial Decree of July 2000, or an annuity, in the case of biological damage greater than $16 \%$. The capital is disbursed in a single payment, whereas the annuity is in monthly instalments, with an initial advance of the first three months. ${ }^{5}$

The term "common disease", on the other hand, is used by the Italian social security system to define disease that is not caused by war, work or service. Protection from common disease, in Italy, is organised by the National Social Security Institute (INPS), which is now the de facto manager of both social security invalidity (sickness cover for insured persons of working age who pay contributions to the institution ${ }^{6}$ ), and of civil incapacity, the social disability protection system that also protects citizens that are unemployed or under working age. ${ }^{7}$ Law 222 of $1984^{8}$ is the legislative benchmark for protection from common disease of the insured person of working age. Article 1 provides for the payment of an allowance to beneficiaries whose work capacity for 'employ- 
ments suitable for capabilities, ${ }^{9}$ is reduced to less than one third. Article 2 establishes the provision of a pension for beneficiaries who have lost their ability to perform any work activity in an absolute and permanent manner. ${ }^{10}$

But how does disability not arising from common disease but from a work-related accident fit the context of INPS social security protection from a medical-legal perspective? In the civil incapacity context, work-related causes cannot be considered for the purpose of estimating the general reduction of the work capacity. As such, by specific provision of Law no. 118 of 1971, ${ }^{11,12}$ work-related accidents are not assessed in the context of civil incapacity. In INPS social security medicine, however, a work-related accident can be the cause, alone or together with other conditions, of a reduction of more than $2 / 3$ of the person's work capacity in employments suitable for his/her capabilities How, then, do we prevent a disability already covered and compensated, in economic terms, by INAIL from being further covered also by INPS? How, in other words, do we avoid the duplication of compensation?

In this context, Law no. 335 of $1995,{ }^{13,14}$ comes to our aid. In article 1, paragraph 43, the Law determines that “... disability pensions, survivor's pensions or the ordinary invalidity allowance covered by the general mandatory insurance for disability, old age and survivors, paid as a result of a work-related accident or occupational disease, cannot be accumulated with an annuity paid for the same incapacitating event, in accordance with the consolidated text of the provisions for insurance against work-related accidents and occupational diseases, approved by decree of the President of the Republic no. 1124 of 30 June 1965, up to the amount of the pension itself. The most favourable social security benefits received at the time of entry into force of this law shall be retained, with adjustment made in relation to future improvements". The article of the law basically defines the conditions under which INPS allowance payments do not accumulate with the INAIL annuity. Paragraph 43 of this article can be applied in an INPS social security disability evaluation, which allows deduction of the INPS allowance from the INAIL annuity, when:

a. The incapacitating event that led to the INAIL annuity and the INPS pension benefit is similar;

b. The incapacitating event caused by a work-related accident is subsequent to a common disease and is such as to aggravate the INPS impairment up to the medical-legal threshold (over $2 / 3$ in employments suitable for capabilities);

c. In the case of multiple infirmities, when the incapacitating event from a work-related accident suffices by itself to determine recognition of a work capacity reduction over $2 / 3$ in employments suitable for capabilities.

On the contrary, paragraph 43 of article 1 of law 335/95 is not applicable when:

a. The INAIL incapacitating event precedes the INPS common disease;

b. The INAIL event does not suffice by itself to determine a working capacity reduction of over $2 / 3$ in employments suitable for capabilities.

\section{Case Reports}

The concepts expressed above may be illustrated with practical cases taken from routine medical-legal evaluation activities:

\section{Case \#1}

A 55-year-old male construction worker with injuries from a work-related accident caused by a fall from height while using self-propelled machinery. Following the fall, which occurred from a height of about three meters, the man suffered a traumatic lesion of the cervical rachis at the C5-C6 level with consequent spastic tetraparesis and a contusive-lacerative trauma of the tendons on the long head of the biceps and the supraspinatus on the right shoulder, both of which were treated surgically. INAIL granted an $80 \%$ recognition of biological damage pursuant to Law 38/2000. The INPS doctor recognised the patient as invalid under Article 1 of Law 222 of June 1984; the doctor determined the applicability of paragraph 43 of article 1 of Law 335/95 since, as stated in the concluding remarks of the medical-legal expert's report, the "debilitating conditions lie completely within the competence of INAIL".

\section{Case \#2}

A 47-year-old male farmer employed in his family winery, with injuries resulting from crushing by a tractor following a fall from the vehicle whilst working. The crushing of the worker's body caused fractures in the D10, D11, D12, L1 and L2 vertebral bodies, with consequent mild paraparesis of the lower limbs and neurogenic bladder. INAIL recognised $74 \%$ biological damage due to the accident.

A few years after the INAIL assessment, the man applied for an ordinary INPS disability allowance, as he was suffering from chronic obstructive pulmonary disease with dyspnea. The medical officer in charge of the INPS medical examination recognised the patient as invalid under article 1 of Law 222 of June 1984 and confirmed the applicability of paragraph 43 of article 1 of Law 335/95 as "the pathology from a work-related cause is sufficient, by itself, to cause a work capacity reduction of more than $2 / 3$ in employments suitable for his capabilities".

\section{Case \#3}

A 52-year-old male mechanical worker assigned to the repair and maintenance of heavy goods vehicles who, while working, suffered a blunt trauma to the lumbar spine with subsequent collapse of the body of the second lumbar vertebra (L2). INAIL recognised the beneficiary as having biological damage of $11 \%$, in accordance with the tables annexed to Law 38/2000.

After a few years, the man applied for an ordinary INPS disability allowance: over the years, he had developed a right shoulder tendinopathy with a moderate functional limitation (the arm can be raised to about half the normal height) and spondylodiscoarthrosis of the cervico-dorsal rachis with a mild-medium degree of functional limitation (flexion-extension and lateral spinal movements are reduced overall by more than $1 / 3$ ). The INPS doctor recognised the subject as invalid under article 1 of Law 222/1984; paragraph 43 of article 1 of Law 335/1995 was not applied as the pathology covered by INAIL played a secondary role in reducing the insured person's working capacity in employments suitable for capabilities by over $2 / 3$.

\section{Case \#4}

A 55-year-old man employed as a pastry chef in a confectionery company. Following a fall at work, the man suffered a trimalleolar fracture of the right ankle, which resulted in ankylosis of the ankle joint and subtalar-mediotarsal complex. INAIL recognised $16 \%$ biological damage in accordance with the tables annexed to Law $38 / 2000$.

A few years later, the insured person applied for an INPS medical examination to qualify for the INPS ordinary invalidity allowance. He had suffered from pancreatitis and post-thrombophlebitic syndrome, which was treated with surgical recanalisation. Based on the positive evolution of the phlebitic picture and the pancreatic condition, the INPS doctor assessed the subject as 
non-invalid under article 1 of Law 222/1984. Obviously, paragraph 43 of article 1 of Law 335/1995 was not applied.

\section{Discussion}

The cases examined illustrate the practical operational procedures to be implemented when the medical-legal evaluation of common diseases, under the INPS social security scheme, must deal with one or more work-related disabilities. The application of paragraph 43, article 1 of Law 335/1995 essentially prevents disabilities already compensated by INAIL from receiving further compensation from INPS. ${ }^{15}$ In other words, the legislator has sought to prevent multiple benefits being paid by different social security institutions for the same incapacitating event. ${ }^{16,17}$ Some legal decisions have been made in this context, which we could define as containment of public spending, such as that of the Court of Cassation no. 16137 of December 2000. ${ }^{18}$ This ruling showed that the legislator's decision was "essentially inspired by considerable financial strictness and justified by the need to contain social security spending, which had increased at the time of the pension reform. Without this express provision, accumulation would normally occur since these are two separate insurance schemes (...) funded by separate contributions (...). In a contingent moment of difficulty in public finance, the legislator can lay down the rule according to which the insured party or their survivors can (...) receive the compensation resulting from a work-related accident or occupational disease once only, without the consequence in social security terms of two distinct allowances deriving from that disability broadly compensating the same reduction in the capacity to work and to earn a living".

In a different jurisprudential orientation, the subsequent rulings of the Court of Cassation no. 5494 of March $2006^{19}$ and no. 22872 of September 2008. ${ }^{20}$ Specifically, the first sentence concerned a worker who had been known to be an invalid INPS for a series of accident-related diseases already protected by INAIL, combined with a common disease, blepharospasm. The merit Judge denied the INPS ordinary invalidity allowance to the worker because blepharospasm alone was not enough to reduce his working capacity, in employments suitable for capabilities, to less than a third. The Court of Cassation, however, had invalidated the previous ruling by claiming that the two invalidities were not entirely overlapping.

This jurisprudential orientation has been confirmed, furthermore, by the recent ruling of the Civil Cassation, Labor section, no. 27510 of October $2019 .{ }^{21}$

Leaving aside the jurisprudential diatribes that have occurred over the years, however, in practical terms, with regard to the monetary liquidation of the claim, what can be done to ensure that the INAIL disability is not compensated by INPS as well? Practically, when INPS grants an ordinary disability allowance of a monetary value higher than that of the INAIL annuity, INPS will only be required to pay the difference between the INPS ordinary invalidity allowance and the INAIL annuity.

\section{Conclusions}

In these few pages, the Authors sought to explain in simple terms, through the use of case studies, the procedures for the medical-legal evaluation of disabilities resulting from work-related disease in the context of the Italian social security system for protection against common diseases. In the ten-years of experience acquired by the Authors in the sector, this has emerged as one of the most sensitive and risky aspects, for medical examiners and for pension liquidation officers, in the routine social insurance evaluation procedures at the INPS Medical Legal Centres (CML).

Failure to indicate the applicability of paragraph 43 , article 1 of Law 335/1995, which is not a rare occurrence, can lead to a duplication of compensation, placing a non-negligible economic burden on the Italian Social Security Institute. In other words, the risk is that the INAIL disability, and the resulting allowance that compensates it, are not adequately highlighted during the INPS medical-legal examination; as a consequence, the work-related disability is further compensated as a common disease.

\section{References}

1. Decree of the President of the Republic no. 1124 of June 30, 1965, published in the Official Journal, General Series, no. 257 of 13 October 1965. Available online at: https://www.gazzetta ufficiale.it/atto/serie_generale/caricaDettaglioAtto/originario?atto.dataPublicationGazzetta=1965-10-13\&atto.codice Redazionale $=065$ U1124\&elenco30giorni $=$ false

2. Macchiarelli L, Arbarello P, Di Luca Nm, Feola T (2005). Medicina Legale, 2a edizione. Ed. Minerva Medica, Turin.

3. Di Luca NM, Feola T, Cecchi R, et al. (2017). Manuale di medicina legale. Ed. Minerva Medica, Turin.

4. Legislative Decree no. 38 of February 23, 2000, published in the Official Journal, General Series, no. 66 of March 20, 2000. Available online at: https:/www.gazzettaufficiale.it/eli/id/ 2000/03/20/000A3221/sg

5. Carinci F, Menegatti E (2015). Labour Law and Industrial Relations in Italy - Update to the jobs act, IPSOA. Wolters Kluwer, Milan.

6. AA.VV. Italy - Incapacity and Disability benefits. In: Employment, Social Affairs \& Inclusion. Available at: https://ec.europa.eu/social/main.jsp?catId=1116\&langId=en\&i ntPageId $=4622$

7. Cimaglia G, Covatta A (2005). L'invalidità civile e la tutela della disabilità. Giuffrè Ed., Milan.

8. Catalano C, De Luca F, Vitiello G (2006). Elementi di medicina legale previdenziale INPS, Giuffrè Ed., Milan.

9. Sammicheli M, Scaglione M (2018). Employment suitable for capabilities: The medical-legal principle in Italian invalidity social security benefits in the current historical work context in Europe. Eur J Social Security (EJSS) 20:242-52.

10. Barni M. Il concetto di permanenza nell'invalidità pensionabile. Giorn Med Leg Inf Toss 1956;2.

11. Law no. 118 of March 30, 1971, published in the Official Journal, General Series, no. 82 of April 2, 1971. Available online at: http://www.handylex.org/stato/1300371.shtml

12. Vitiello G, Catalano C, Antonelli F, et al (2007). Invalidità civile, disabilità, handicap. C.G. Edizioni Medico Scientifiche, Turin.

13. Law no. 335 of August 8, 1995, published in the Official Journal, General Series, no. 198 of August 25, 1995. Available online at: https://www.gazzettaufficiale.it/eli/id/1995/08/25/ 095A4970/sg

14. van Vugt JPA, Peet JM (2000). Social security and solidarity in the European Union: Facts, evaluations, and perspectives. Springer-Verlag, Berlin.

15. Oliphant K, Wagner G (2012). Employer's liability and workers' compensation. Tort and insurance law, vol. 31, W. de Gruyter, Berlin.

16. Assennato GS (2001). Osservazioni sul cumulo tra prestazioni 
Inps e Inail (art. 1, comma 43, legge n. 335/1995) (Cassazione, 22/12/00, no. 16135). Rivista Giuridica Lavoro Previdenza Sociale 52:696-705.

17. Persiani M, D’Onghia M (2018). Fondamenti di diritto della previdenza sociale. 2 a edizione G. Giappichelli Ed., Turin.

18. Supreme Court, Labour Section, sentence no. 16137 of December 22, 2000. In: Foro Italiano 2001;126:1921-6. Available online at: https://www.jstor.org/stable/23197397?seq $=1 \#$ page_scan_tab_contents
19. Supreme Court, Labour Section, sentence no. 5494 of March 14, 2006. In: DE MATTEIS A, Infortuni sul lavoro e malattie professionali, Seconda Edizione, Giuffrè Editore, Milan, 2016.

20. Supreme Court, Labour Section, sentence no. 22872 of September 9, 2008.

21. Supreme Court, Labour Section, sentence no. 27510 of October 28, 2019. Available online at: https://sentenze. lalegge pertutti.it/sentenza/cassazione-civile-n-27510-del-28$10-2019$
Correspondence: Michele Sammicheli,

sammicheli@alice.it / michele.sammicheli01@inps.it

Authors' contributions: The Authors contributed equally to the conception and design of the work, to the acquisition, analysis and interpretation of data for the work. The Authors approve this version to be published.

Conflict of interests: The Authors declare no conflict of interest.

Key words: work-related accident; Italian social security medicine; Italian law 335/1995.

Parole chiave: infortunio sul lavoro; medicina previdenziale INPS; legge italiana 335/1995.

Palabras clave: accidente de trabajo; medicina de seguridad social de Italia; ley italiana ${ }^{\circ} 335$ del 8 de agosto de 1995.

Received for publication: 19 November 2019.

Accepted for publication: 30 December 2019.

This article is distributed under the terms of the Creative Commons Attribution Noncommercial License (by-nc 4.0) which permits any noncommercial use, distribution, and reproduction in any medium, provided the original author(s) and source are credited.

${ }^{\circ}$ Copyright: the Author(s), 2019

Licensee PAGEPress, Italy

Rivista di Psicopatologia Forense, Medicina Legale, Criminologia 2019; $24: 65$

doi:10.4081/psyco.2019.65 